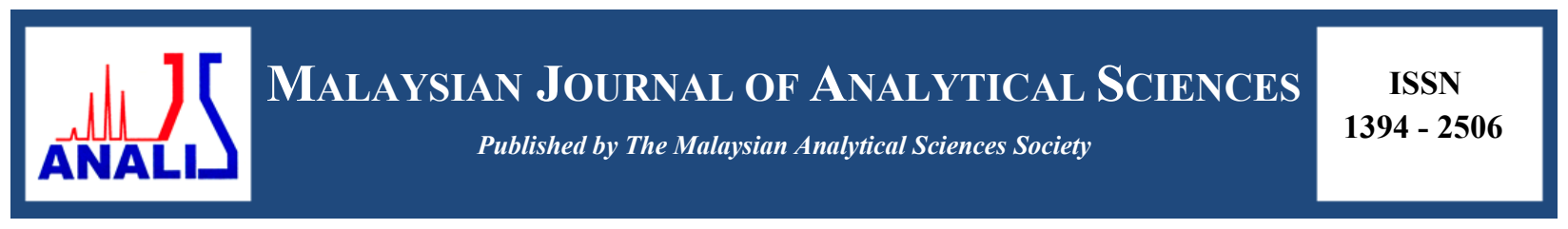

\title{
INTERCALATION STUDY OF CURCUMIN INTO ZINC LAYERED HYDROXIDE
}

\author{
(Kajian Mengenai Penyisipan Kurkumin ke dalam Zink Hidroksida Berlapis) \\ Adila Mohamad Jaafar ${ }^{1}$, Asma Najaj Anuar ${ }^{1}$, Norhayati Hashim², Fatin Hanifah Ayob ${ }^{1}$ \\ ${ }^{1}$ Department of Chemistry, Faculty of Science, \\ Universiti Putra Malaysia, 43400 UPM Serdang, Selangor, Malaysia \\ ${ }^{2}$ Department of Chemistry, Faculty of Science and Mathematics \\ Universiti Pendidikan Sultan Idris, 35900 Tanjong Malim, Perak, Malaysia \\ *Corresponding author: adilamj@upm.edu.my
}

Received: 17 August 2015; Accepted: 5 October 2016

\begin{abstract}
Zinc layered hydroxide (ZLH) intercalated with curcumin was successfully prepared by ion exchange method. The synthesised nanocomposite was characterised by Powder X-ray diffraction (PXRD) and Fourier transform infrared spectroscopy (FTIR). The obtained intercalation compound, ZLH-curcumin nanocomposite (ZiCUR), showed a basal spacing of $10.0 \AA$ when $0.01 \mathrm{M}$ of curcumin solution was used in the synthesis. The shifting in the stretching frequency of the curcumin anion provides strong evidence that the anion is bonded to the ZLH through electrostatic force. In FTIR, after intercalation, there is a noticeable shift of the $\mathrm{O}-\mathrm{H}$ stretching vibrational bands. This is due to the formation of strong hydrogen bonds between curcumin and $-\mathrm{OH}$ groups in ZLH. Thus, this indicates that curcumin anions are present in the sample and were intercalated between positively charged ZLH layers, as indicated by the characteristics of PXRD pattern.
\end{abstract}

Keywords: zinc layered hydroxide, curcumin, ion exchange method

Abstrak

Zink hidroksida berlapis (ZHB) disisip bersama kurkumin telah berjaya disediakan menggunakan kaedah pertukaran ion. Komposit nano yang telah di sintesis dicirikan menggunakan X-ray Serbuk Pembelauan dan Spektroskopi Infra Merah Transformasi Fourier. Sebatian interkalasi yang diperoleh iaitu komposit nano zink hidrosida berlapis-kurkumin, menunjukkan jarak basal sebanyak $10.0 \AA$ apabila kepekatan 0.01M larutan kurkumin digunakan semasa proses sintesis. Perubahan pada frekuensi anion kurkumin menunjukkan bukti yang kukuh di mana anion telah dilekatkan kepada ZHB menggunakan daya elektrostatik. Melalui Spektroskopi Infra Merah Transformasi Fourier, selepas interkalasi, perubahan yang ketara pada O-H regangan jalur getaran dapat di lihat. Hal ini kerana, pembentukan ikatan hidrogen yang kuat antara kurkumin dan kumpulan $\mathrm{OH}$ di dalam ZHB. Maka, ia menunjukkan bahawa anion kurkumin hadir di dalam sampel dan telah disisipkan antara lapisan ZHB yang bercas positif, seperti mana yang ditunjukkan oleh ciri - ciri corak Spektroskopi Infra Merah Transformasi Fourier.

Kata kunci: zink hidroksida berlapis, kurkumin, kaedah pertukaran ion

\section{Introduction}

According to the World Health Organization, open injuries have the potential for serious bacterial wound infections, including gas gangrene and tetanus, and these, in turn, may lead to long term disabilities, chronic wound or bone infection, and death [1]. Wound infection is particularly of concern when injured patients are presented late for definitive care. Problems, such as lack of knowledge about how to diagnose and treat wounds and lack of funding to 
proper therapies, medical technologies and trained wound-care professionals, will lead to millions of untreated and mistreated patients each year.

Turmeric, (Curcuma longa L.), has been used in traditional medical applications since ancient times. The principal curcuminoid in turmeric is curcumin [2], which was extensively studied as antibacterial compound. The wound healing ability of curcumin, involving the mechanisms of reduced inflammation, granulation, and remodelling of the tissue, was intensively examined in rats and guinea pigs. The recent studies have highlighted that punch wounds in curcumin-treated animals healed much faster than curcumin untreated animals [3] [4]. However, the curcumin molecule is unstable and therefore, demonstrates limited biological activity and practical applications. In this study, in order to stabilize the curcumin, attempts were made by intercalating curcumin into layered metal hydroxide.

Layered metal hydroxide can be classified as layered double hydroxide (LDH) and layered hydroxide salt (LHS). Layered double hydroxide (LDH) nanocomposite is a class of inorganic material with a chemical composition represented by the general formula, $\left[\mathrm{M}^{2+}{ }_{1-\mathrm{x}} \mathrm{M}^{3+}{ }_{\mathrm{x}}(\mathrm{OH})_{2}\right]{ }^{\mathrm{x}+}\left[\mathrm{A}^{\mathrm{n}-}{ }_{\mathrm{x} / \mathrm{n}} \cdot \mathrm{mH}_{2} \mathrm{O}\right]$, where $\mathrm{M}^{2+}$ and $\mathrm{M}^{3+}$ are divalent and trivalent metal cations, respectively [5]. Previous studies have shown that curcumin intercalated into $\mathrm{Mg} / \mathrm{Al} \mathrm{LDH}$ exhibited excellent wound healing properties [6]. However, to the best of our knowledge, the application of a Zinc layered hydroxide salt (LHS) as a host has yet to be explored.

Zinc layered hydroxide (ZLH) is represented by the general formula of $\mathrm{M}^{2+}(\mathrm{OH})_{2-\mathrm{x}}\left(\mathrm{A}^{\mathrm{m}-}\right)_{\mathrm{x} / \mathrm{m}} \cdot n \mathrm{H}_{2} \mathrm{O}$, where $\mathrm{M}^{2+}$ in this case is the metal cation $\mathrm{Zn}^{2+}$ and $\mathrm{A}^{\mathrm{m}-}$ is the counter ion [7]. The ZLH structure consists of positively charged layers that can expand or contract depending on the nature of the interlayer anions. In this current investigation, we study the intercalation of curcumin into interlayer galleries of ZLH via ion exchange method, as well as properties of the resulting ZLH-curcumin intercalation compound. This direct method involved a direct reaction between the curcumin solution and the zinc oxide $(\mathrm{ZnO})$ precursor. Compared with other LHS synthesis methods, like urea hydrolysis [8], structural memory effects [9], co-precipitation [10] and solid state reactions [11], ion exchange method was chosen as the best method because it is simple, environmentally friendly, and economical as it involves fewer chemicals and fewer steps.

\section{Materials}

\section{Materials and Methods}

Zinc oxide, $99 \%$, curcumin $\left(\mathrm{C}_{21} \mathrm{H}_{20} \mathrm{O}_{6}\right.$ molecular weight $\left.368.3799 \mathrm{~g} / \mathrm{mol}\right), 98 \%$, and sodium hydroxide, $99 \%$ purity, were purchased from Acros Organics (Geel, Belgium) and Merck (Darmstadt, Germany), respectively. Chemicals were used without further purification. Deionized water was used throughout the experiment.

\section{Synthesis of zinc layered hydroxide intercalated with curcumin}

The curcumin-intercalated ZLH was prepared using the ion-exchange method [12,13,14]. An amount of $100 \mathrm{~mL}$ of Curcumin at $0.01 \mathrm{M}$ was added to the aqueous solution containing $1.0 \mathrm{~g} \mathrm{ZnO}$. The mixture was stirred vigorously for 2 hours at room temperature. The reaction mixture was aged at $70{ }^{\circ} \mathrm{C}$ for 18 hours before the resulting slurry was centrifuged, washed with water, dried in an oven at $70{ }^{\circ} \mathrm{C}$, and kept for further characterisation.

\section{Characterisation}

Powder X-ray diffraction (PXRD) patterns were recorded with a XRD-6000 (Shimazdu, Kyoto, Japan) using CuK $\alpha$ radiation $(\lambda=1.5418 \AA)$ at $30 \mathrm{kV}$ and $30 \mathrm{~mA}$. Fourier transform infrared (FTIR) spectra were recorded over the range of $400-4000 \mathrm{~cm}^{-1}$ on a Perkin-Elmer Spectrum 100 (Perkin-Elmer, Waltham, Massachusetts, USA) equipped with a universal attenuated total reflectance (ATR) accessory.

\section{Powder X-ray diffraction analysis}

\section{Results and Discussion}

Figure 1 shows the PXRD patterns of $\mathrm{ZnO}$ and $\mathrm{ZLH}$-curcumin nanocomposite (ZiCUR). The PXRD pattern of $\mathrm{ZnO}$ showed characteristics of high crystallinity peaks. However, in ZiCUR, the peak of $\mathrm{ZnO}$ phase still dominated the PXRD pattern, which is due to an incomplete reaction. The intercalation occurred when the $\mathrm{ZnO}$ was transformed to ZLH and the curcumin anion was intercalated between the layers. This can be observed by the presence of peaks at a lower $2 \theta$ value, as shown in the diffraction patterns of ZiCUR. The expansion of the basal spacing recorded at 
$10.0 \AA$ was caused by a larger molecular size of curcumin, as well as the spatial arrangement of the anion in the interlayer space. From previous studies, it was proposed that the formation of ZiCUR from ZnO occurred in three steps through a dissociation-deposition mechanism [15,16,17]. The first step described in Eq. 1 involves hydrolysis of $\mathrm{ZnO}$ in water. When $\mathrm{ZnO}$ particles are immersed in the water, the surface of $\mathrm{ZnO}$ hydrolyses to form a layer of $\mathrm{Zn}(\mathrm{OH})_{2}$. The layer of $\mathrm{Zn}(\mathrm{OH})_{2}$ that is formed then becomes more soluble than $\mathrm{ZnO}$ in the presence of acid to become $\mathrm{Zn}^{2+}$ and $\mathrm{OH}^{-}$(Eq. 2). Finally, the $\mathrm{Zn}^{2+}$ species, hydroxyls, $\mathrm{H}_{2} \mathrm{O}$, and curcumin anions (CA) in the solution react to generate the layered intercalation compound (Eq. 3). The process is repeated until all the $\mathrm{ZnO}$ phase and the $\mathrm{Zn}(\mathrm{OH})_{2}$ phase has completely converted to the layered compound. ZiCUR is formed from the host-guest interactions, namely electrostatic attraction, hydrogen bonding, and van der Walls forces [18]. The mechanism of dissociation-deposition is described in the equations below:

$$
\begin{aligned}
& \mathrm{ZnO}+\mathrm{H}_{2} \mathrm{O}->\mathrm{Zn}(\mathrm{OH})_{2} \\
& \mathrm{Zn}(\mathrm{OH})_{2}->\mathrm{Zn}^{2+}+2 \mathrm{OH}^{-} \\
& \mathrm{Zn}^{2+}+2 \mathrm{OH}^{-}+\mathrm{CA}^{-}+\mathrm{H}_{2} \mathrm{O}->\mathrm{Zn}^{2+}(\mathrm{OH})_{2-\mathrm{x}}\left(\mathrm{CA}^{-}\right)_{\mathrm{x}} n \mathrm{H}_{2} \mathrm{O}
\end{aligned}
$$

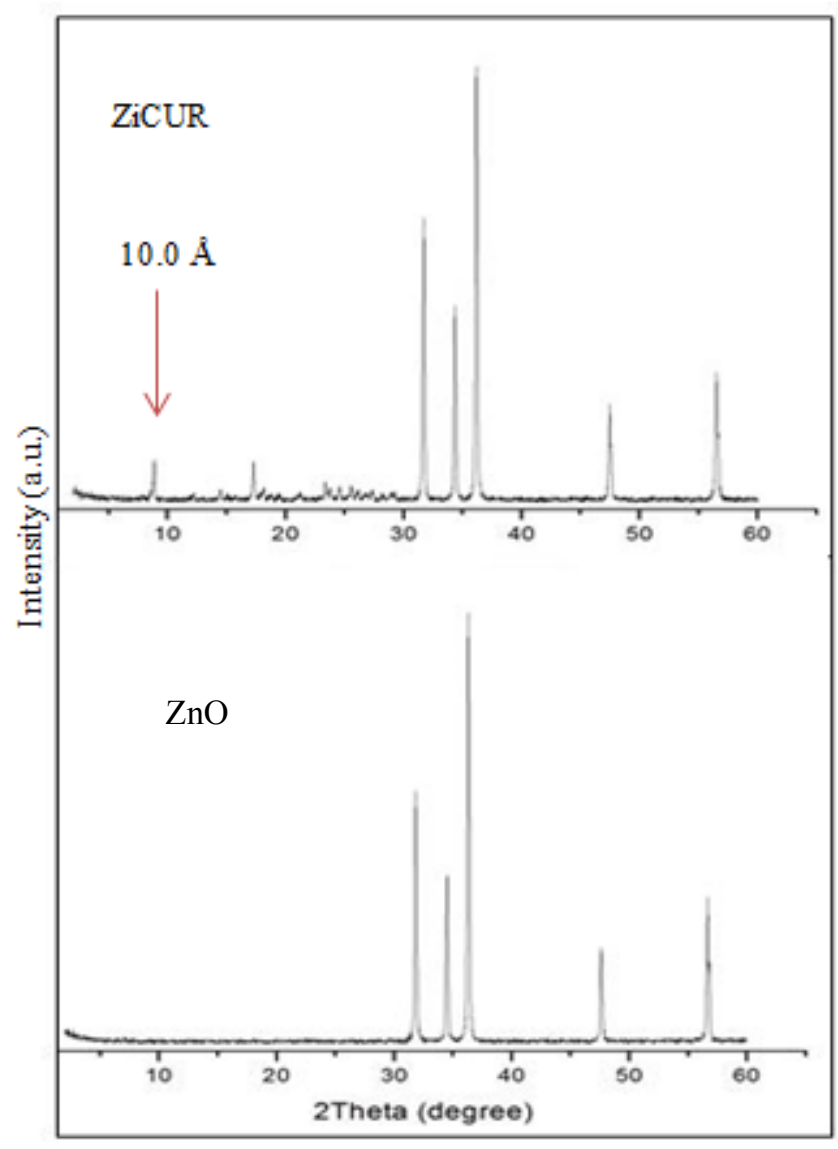

Figure 1. PXRD patterns of $\mathrm{ZnO}$ and $\mathrm{ZiCUR}$ compounds

\section{Fourier transform infrared analysis}

The presence of the curcumin in the ZLH interlayers was also elucidated by FTIR spectroscopy, which supported the PXRD results [19]. Figure 2 exhibited the FTIR spectrum of pure $\mathrm{ZnO}$, curcumin, and ZiCUR. The sharp and 
intense peak of $\mathrm{ZnO}$ at the lower wavenumber range, $400 \mathrm{~cm}^{-1}$ is due to the $\mathrm{Zn}-\mathrm{O}$ sublattice stretching vibration [20]. Similar absorption bands could also be observed for the ZiCUR, as it possesses the same functional group. The FTIR spectra of curcumin showed strong characteristic vibrations at $1592 \mathrm{~cm}^{-1}$ attributed to $\mathrm{C}=\mathrm{C}$ bending and 1270 $\mathrm{cm}^{-1}$ to C-O stretching. Trans-C-H out-of-plane bend for curcumin was detected at $960 \mathrm{~cm}^{-1}$. The C-H monosubstitution band for phenyl group could be detected at $720 \mathrm{~cm}^{-1}, 809 \mathrm{~cm}^{-1}$, and $856 \mathrm{~cm}^{-1}$.

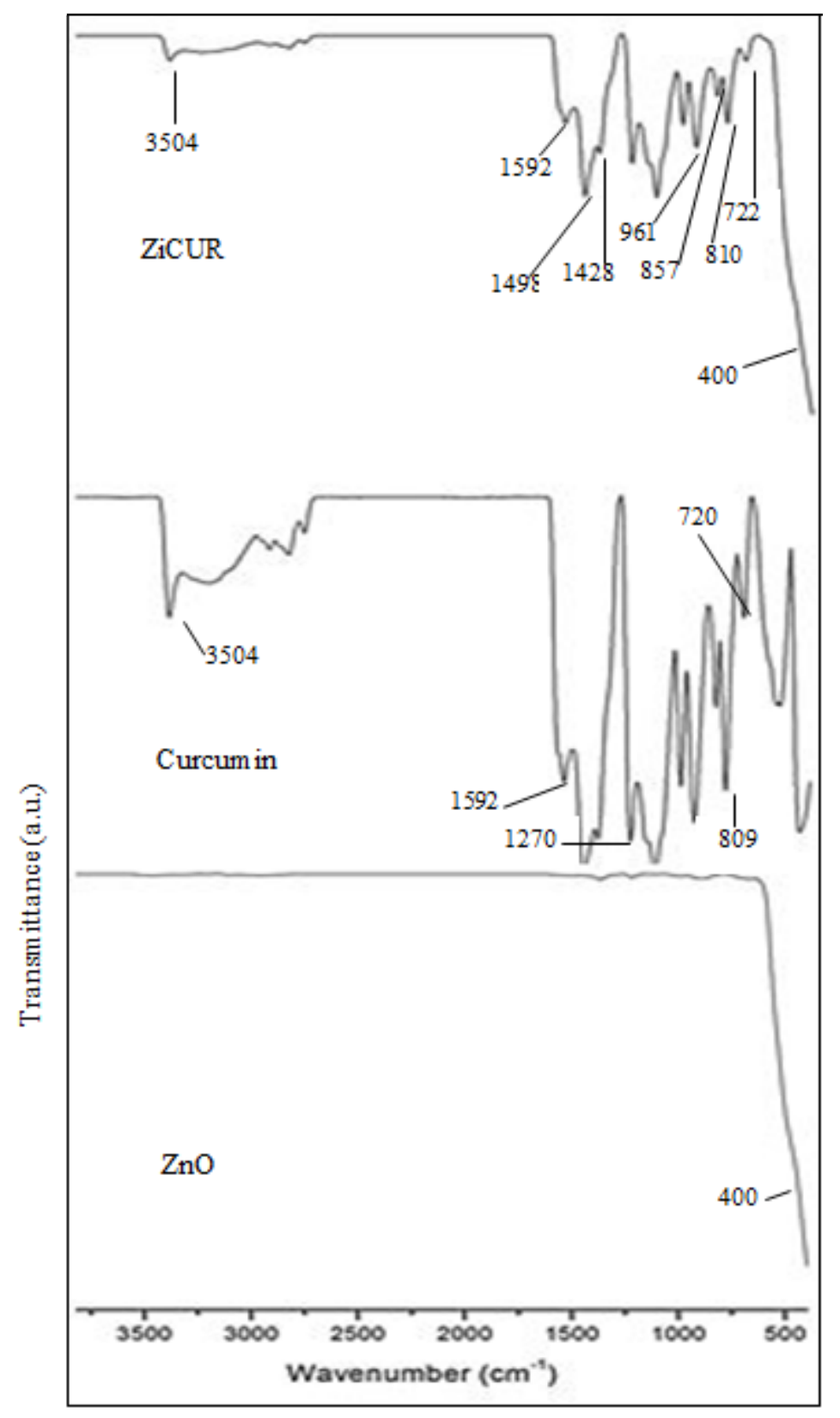

Figure 2. FTIR spectra of $\mathrm{ZnO}$, Curcumin and ZiCUR compounds 
On the other hand, the intercalation compound exhibited most of the vibrations assigned of curcumin, although several vibrations shifted due to the interaction between the curcumin anion and the interlayer. In particular, vibrations were due to trans-C-H out of plane bend at $961 \mathrm{~cm}^{-1}$ and $\mathrm{C}-\mathrm{H}$ monosubstitution band at $722 \mathrm{~cm}^{-1}, 810$ $\mathrm{cm}^{-1}$ and $857 \mathrm{~cm}^{-1}$. $\mathrm{COO}^{-}$stretching of intercalated curcumin anion overlapped and appeared at $1498 \mathrm{~cm}^{-1}$ and $1428 \mathrm{~cm}^{-1}$. The $\mathrm{C}=\mathrm{C}$ stretch in intercalated ZLH also overlapped at $1592 \mathrm{~cm}^{-1}$. The broad band at $3504 \mathrm{~cm}^{-1}$ was assigned to the $\mathrm{O}-\mathrm{H}$ stretching of vibration of interlayer water molecules. These results indicate that both curcumin and $\mathrm{ZnO}$ functional groups were present in the compound and further confirmed the intercalation of curcumin between positively charged ZLH layers, as indicated by the characteristics of PXRD pattern.

\section{Conclusion}

The curcumin anion was successfully intercalated into the Zn layered hydroxide by the ion exchange method. The interlayer spacing of ZiCUR obtained by PXRD characterization suggests the successful intercalation reactions between ZLH nanolayers and curcumin. The FTIR spectra further confirmed the presence of curcumin in the ZLH. The product, therefore, is hoped to demonstrate future potential as wound dressings for human skin.

\section{Acknowledgement}

The authors thank the Ministry of Higher Education for funding this project under grant FRGS- 5524557. The author (Asma Najaj Anuar) is grateful to the Department of Chemistry Faculty of Science Universiti Putra Malaysia for providing the essential laboratory facilities and Universiti Putra Malaysia for Graduate Research Fellowship.

\section{References}

1. Wound Reach Foundation (2015). Online from http://www.woundreach.org/why-wounds/the-challenge [Accessed date 2015-06-27].

2. Gadekar, R., Saurabh, M. K., Thakur, G. S. and Saurabh, A. (2012). Study of formulation, characterisation and wound healing potential of transdermal patches of curcumin. Asian Journal of Pharmaceutical and Clinical Research, 5(4): 225 - 230.

3. Bharat, B., Kumar, A., Aggarwal, M. S. and Shishodia, S. (2005). Curcumin derived from turmeric (Curcuma Longa): A spice for all seasons. Phytopharmaceuticals in Cancer Chemoprevention, 23: $351-387$.

4. Kamkanam, M., Samindra, S. and Kottegoda, N. (2014). Encapsulation of curcumin into layered double hydroxides. Nanotechnology Reviews, 3(6): 579 - 589.

5. Aminu, U. K., Hussein, M. Z., Fakurazi, S. and Arulselvan, P. (2014). Layered double hydroxide nanocomposite for drug delivery systems; bio-distribution, toxicity and drug activity enhancement. Chemistry Central Journal, 8: $47-55$.

6. Cao, G. T., Xing, F. F., Wang, P. and Ni, Z. M. (2008). Synthesis, characterization and release of curcuminintercalated Mg-Al-layered double hydroxides. Chinese Journal of Inorganic Chemistry, 24(6): 956 - 963.

7. Ramli, M., Hussein, M. Z. and Yusoff, K. (2013). Preparation and characterization of an anti-inflammatory agent based on a zinc-layered hydroxide-salicylate nanohybrid and its effect on viability of Vero-3 cells. International Journal of Nanomedicine, 2013 (8): 297 - 306.

8. Kang, H., Leoni, M., He, H., Huang, G. and Yang, X. (2012). Well-crystallized $\mathrm{CO}_{3}{ }^{2-}-$ type LiAl-LDH from urea hydrolysis of an aqueous chloride solution. European Journal of Inorganic Chemistry, 2012(24): 3859 3865 .

9. Hussein, M. Z., Ghotbi, M. Y., Yahaya, A. H. and Rahman, M. Z. A. (2009). Synthesis and characterization of (zinc-layered-gallate) nanohybrid using structural memory effect. Materials Chemistry and Physics,113 (1): $491-496$.

10. Hussein, M. Z., Jaafar, A. M., Yahaya, A. H. and Zulkarnain, Z. (2009). The effect of single, binary and ternary anions of chloride, carbonate and phosphate on the release of 2, 4-dichlorophenoxyacetate intercalated into the Zn-Al-layered double hydroxide nanohybrid. Nanoscale Research Letters, 4 (11): 1351 - 1357.

11. Rajamathi, M. and Kamath, P. V. (2001). Urea hydrolysis of cobalt(II) nitrate melts: synthesis of novel hydroxides and hydroxynitrates. International Journal of Inorganic Materials, 3 (7): 901 - 906.

12. Hussein, M. Z., Rahman, N. S. S. A., Sajiro, S. H. and Zainal, Z. (2012). Herbicide-intercalated zinc layered double hydroxide nanohybrid for a dual-guest controlled release formulation. International Journal of Molecular Sciences, 13: 7328 - 7342. 
13. Hashim, N., Muda, Z., Hamid, S. H., Isa, I. M., Kamari, A., Mohamed, A., Hussein, M. Z. and Ghani, S. A. (2014). Characterization and controlled release formulation of agrochemical herbicides based on zinc-layered hydroxide-3-(4-methoxyphenyl) propionate nanocomposite. Journal of Physical and Chemical Sciences, 1(4): $1-6$.

14. Hashim, N., Hussein, M. Z., Isa, I. M., Kamari, A., Mohamed, A., Jaafar, A. M. and Taha, H. (2014). Synthesis and controlled release of cloprop herbicides from cloprop-layered double hydroxide and cloprop-zinc-layered hydroxide nanocomposites. Open Journal of Inorganic Chemistry, 4: 1 - 9.

15. Bang, S., Lee, S., Ko, Y., Park, J., Shin, S., Seo, H. and Jeon, H. (2012). Photocurrent detection of chemically tuned hierarchical $\mathrm{ZnO}$ nanostructures grown on seed layers formed by atomic layer deposition. Nanoscale Research Letters, 7: 290 - 301.

16. Hussein, M. Z., Ali, S. H. A., Zainal, Z. and Hakim, M. N. (2011). Development of antiproliferative nanohybrid compound with control release property using ellagic acid as the active agent. International Journal of Nanomedicine, 6: 1373 - 1383.

17. Xingfu, Z., Zhaolin, H., Yiqun, F., Su, C., Weiping, D. and Nanping, X. (2008). Microspheric organization of multilayered $\mathrm{ZnO}$ nanosheets with hierarchically porous structures. Journal Physical Chemistry C, 112: $11722-11728$.

18. Mohsin, S. M. N., Hussein, M. Z., Sajiro, S. H., Fakurazi, S., Arulselvan, P. and Hin, T.Y.Y. (2013). Synthesis of (cinnamate-zinc layered hydroxide) intercalation compound for sunscreen application. Chemistry Central Journal, 7(1): $26-32$.

19. Lv, L., Sun, P., Gu, Z., Du, H., Pang, X., Tao, X., Xu, R. and Xu, L. (2009). Removal of chloride ion from aqueous solution by $\mathrm{ZnAl}-\mathrm{NO}_{3}$ layered double hydroxide as anion-exchanger. Journal of Hazardous Materials, 161: $1444-1449$.

20. Hussein, M. Z., Hashim, N., Yahya, A. H. and Zainal, Z. (2010). Synthesis and characterization of [4-(2,4dichlorophenoxybutyrate)-zinc layered hydroxide] nanohybrid. Solid State Sciences, 12: 770 - 775. 